\title{
Design of Reorganization Scheme for Business Process of Electric Power Marketing
}

\author{
Lixia Lou, Tie Guo, Yongchao Lou and Hao Huang
}

\author{
State Grid Jiangxi Electric Power Research Institute, Jiangxi Nanchang 330096
}

\begin{abstract}
Keywords: Power marketing; Business process reorganization; Program design
\end{abstract}
\begin{abstract}
Commercialization of electricity market is a new trend in the development of China's electric power industry. Power supply marketing management is the core work of the power supply enterprises to deepen the reform and integrate into the socialist market economy. It is the key process and key route in the power supply network. The power enterprises should improve their competitive advantage and take social responsibility better, and rely on the degree of management modernization and provide customers with high quality power and high standard service. Especially in the deep market economy reform, the power industry is facing fierce market competition, in order to gain an advantage in the market competition, they need to do a good job of the various services in every link of sales, prevent the risk of the service effectively, so as to ensure that they can provide high quality and effective services for the power customers. This paper discusses the related contents of the process reorganization of power marketing business, and analyzes the guarantee system of establishing the marketing business process in detail.
\end{abstract}

\section{Introduction}

With the deepening development of China's electric power enterprise reform, power users put forward higher requirements of the power quality, service quality and efficiency to power supply enterprises. Breaking the business monopoly, introducing competition mechanism, implementing the new mechanism of the electricity market commercial operation is the inevitable trend of China's power industry development. The power industry is transferring from the planned economy to the market economy currently, corporate restructuring, commercial operation, legal management, have been turned "on paper" into the steady progress stage. Power supply companies must seek a new marketing strategy, a new marketing mechanism to adapt to the new situation. This kind of marketing strategy must completely abandon the dependence on administrative means, the planned economic, from the perspective of self-management, the perspective of market economy and the perspective of quality services to seek commercialization of electric marketing new mechanism and marketing new way. Business process reorganization is mainly carrying out integrated transformation on the original functional management structure with too detailed parts, could maximize the process to simplify the process, highlight the essence, refine the essence, create quality, achieve proficiency, implement precision, and internal only "fine".

\section{Basic Business of Power Marketing}

The basic business of power marketing can be divided into: business expansion, change of electricity business, business electric charge management, electricity price management, energy metering management, power supply contract management, electricity inspection and marketing audit.

Business Expansion. Business expansion is also known as asking for installation. That is, the new equipment installation and capacity expansion for customers to complete the necessary registration procedures and some business procedures.

Change the Eectricity Business. Under the situation that customers do not increase the capacity and power supply circuit, due to their own business, production, construction, life and other changes, they apply for changes to the power supply enterprises, asked to change agreed electricity business 
in the "electricity contract".

Electricity Fee Management. Electricity fee management includes meter reading, accounting, charge management.

Electric Price Management. At present, for electricity price, China take the form of government pricing. The principle is "unified leadership, hierarchical management".

Supply and Use Electricity Contract. The electricity supply and use contract is the power supply enterprises supply electricity to power customers, electricity customers pay electricity contract.

Electricity Inspection and Marketing Audit. The electricity inspection is an activity of checking the user's power usage and electricity behavior. Marketing audit is an activity that the power supply enterprises make the inspection to all links in the electrical business.

\section{Current Situation of Power Marketing Management}

There are some common problems in the business processes of domestic electric power enterprises:

The Lack of a Unified Business Process Description Language and Tools in Enterprise. Different internal organizational units and department process using different methods of description, they are easy to talk about themselves in the process of internal business communication and interaction, can't communicate effectively, hindering the integration of cross-sectoral processes and the promotion of best practices. This is particularly evident in large enterprise groups, affecting the business collaboration and the refinement and promotion of business units.

The Process Description of Multi-management Themes Coexist. Within the enterprise departments or organizations, according to their business needs, such as the requirements of quality management department to pass the ISO certification, the requirement of environmental protection departments from the HSE system, the requirement of internal control departments to comply with the SOX bill, respectively, so that a number of process designs (description) were carried out to form a large number of documents. These process documents describe some of the business activities repeatedly, which not only increase the workload of the process description, but also business people need to refer to different process documents in the actual business process (specification), affecting the efficiency.

The Lack of a Unified Process Architecture, Lack of Joins and Coordination between Processes, Forming Process Islands. Process design work was carried out from point of view of a single department or management theme within the enterprise process usually lack of the overall consideration for business operations activities in the enterprise, limited to the business needs of the sector, the process between the various departments and management issues can't be connected, Information sharing and delivery are difficult, there are a lot of process breakpoints, so it is difficult to form an end-to-end process system, affecting the entire business process operation efficiency, cost, quality, can't meet customer' needs in the fierce competition market environment.

Information System becomes "Black Box" of the Process, Hindering the Continuous Improvement of the Process. With the development of information technology, more and more information systems such as ERP, CRM, SRM and so on are widely used, therein, some of which information system can achieve the work of curing and automation, improve process efficiency. Enterprises are on the way to realize implementation of these information systems, usually first make process description, and then according to the process description to carry out the system configuration, but in the process of information system using and maintenance, making the process of the configuration adjustment, will not modify the description file, while the original process description file can't reflect the information system embedded process status. After a period of implementation of the system, due to the system automation to the process, the relevant business people have usually ignored its embedded business processes. At this time, neither the exact description of these processes nor the business staff who can clearly understand these processes, the information system is actually a "black box" of the process. 


\section{Research on the Design of Business Process Reorganization of Electric Power Marketing}

The design of business process reorganization of marketing professional intensive management model.

The establishment of enterprise decision-making, marketing, macro management and customer service centers and other business services as the core of the structured, clear function of the decision-making level, management level and business level three marketing and service management model.

Customer Service Center is mainly responsible for business asking for installation and related services, four sub-centers following that:

Electricity sales asking for installation sub-center, responsible for accepting the user expansion equipment applications and non-engineering industry expansion project management business;

Project management sub-center, responsible for the project industry expansion in the whole process of management from accepting the demand of expansion information to the completion of the project qualified delivery to electricity, customer project manager supply racking service for customer service project;

Customer call sub-center, by telephone 95598, fax, short message, paging, Email, etc., provide all types of customers with electricity business consulting, inquiries, and accept the electricity business, power failure repair, complaints and suggestions;

Information management sub-center, responsible for information of industry expansion, electricity contracts, complaints handling management, collect and analyze market information, power outage information, undertake operation and management of power marketing technical support system. Customer service center sets up a number of business outlets according to customer distribution and business needs.

The design of reorganization scheme of integrating sales and operation intensively management model

Regional power supply enterprises temporarily don't set up a customer service center, electricity accounting processing center and fault repair center, but establish the marketing department, make a unified management and supervision for the county power supply enterprise marketing work. District power supply enterprises set up electric energy measurement center, responsible for the energy meter verification and distribution. According to the actual situation, the county power supply enterprises can also be responsible for low-pressure single meter test.

The formation of professional meter reading company

Forming professional meter reading company should adapt to the method of taking the first pilot, steady way to promote. In the Xining City and Golmud City, to take the pilot, after the accumulation of experience, we can continue to promote. Meter reading company are set up by the power of multi-enterprise-based in principle, is the multi-enterprise subsidiary with a legal personality, its nature is the collective enterprises, as a purely labor-oriented companies, only undertake the meter reading work, do not assume other power supply business. Meter reading company employees are generally the main business reduction staff and social recruitment staff. Social staff can be recruited from the enterprise laid-off workers, or through introduction of the intermediary agencies to standardize the operation.

Explore the approach of community paid services

Actively promote the community service forces to carry out non-property supply facilities paid services (mainly the power facilities, such as fault repair business within residential property rights), by the multi-business, property community to set up maintenance stations, and gradually transfer this part of the service into social service.

\section{Summary}

The purpose of the reorganization of the power marketing business is to change the defects in the marketing business process of the company, and to improve the management efficiency, management relationship, management methods, strengthen management function, improve the 
efficiency of work, reinforce the ability to adapt to market according to the requirements of marketization and intensive management, to maximize the power, service optimization, efficiency and value-added, to maximize the national economy and social needs. Electric power enterprises should attach great importance to the improvement of power marketing management system, only that, the power economy will be long-term stable development, so that power marketing programs and methods can show the function effectively. We should develop a clear power marketing strategy, and innovate and reform continually with the market demand changes, improve the quality of service and the overall quality level of staff, do well in all the sales before, sales and after sales service work, fully understand the needs of customers to develop and produce power products to meet customers' demands, promote power companies economic growth, to achieve the goal of maximizing the economic efficiency of enterprises.

\section{References}

[1] X.Du, The Development and Application of Geographical Information System on Power Marketing Business Expanding [J]. Electrical Engineering, 2010, 132(5):689-694.

[2] H.E Weimin, Y Zou and L Wang, Research on Electric Power Marketing Service Risk Based on Customer Perspective [J]. Modern Electronics Technique, 2016.

[3] X U Jie-Yan, M I Xin-PingM, Analysis of Power Marketing in Japan [J]. Power Demand Side Management, 2012.

[4] S Yan, S.T Wang and R.M Yuan, et al. Design of the Communication Module of Smart Handheld Terminal in Power Marketing[C] CICED 2010 Proceedings. IEEE, 2010:1-5.

[5] Z Wang, Informatization Construction of Power Marketing Based on Big Data Platform [J]. Inner Mongolia Electric Power, 2016.

[6] H Liu, The analysis of China Electric Power Marketing and Strategies[C] Circuits, communications and System. IEEE, 2010:394-397.

[7] J Meng, Y Yang, The Application of Improved Decision Tree Algorithm in the Electric Power marketing[C] World Automation Congress. IEEE, 2012:1-4.

[8] Q Lin, Analysis on Main Problems and Countermeasures of Electric Power Marketing in Electric Power Market [J]. Wireless Internet Technology, 2016.

[9] S.C Han, Y.L Zhang and L.Y Zhang, Benefit Analysis of Mobile Inspection Operation Terminals in Electric Power Marketing [J]. Power Demand Side Management, 2016.

[10] M.A Shi-Lin, Y.E Chuan-Hai and M.G Qiu, Discussions on Electric Power Marketing Development Bottleneck and Countermeasures [J]. Power Demand Side Management, 2010.

[11] A Zhao, Analysis on the Efficiency of Improving Meter Reading in Power Marketing [J]. Modern Industrial Economy: Informationization, 2015.

[12] W.W La, Power Marketing System Performance Optimization Analysis and Research [J]. Mechanical: Electrical Engineering Technology, 2014. 